\title{
Документалното наследство на Кирила Възвъзова-Каратеодорова в Националната библиотека „Св. Св. Кирил и Методий“
}

AвStRact: Bozhilova Radina, Dokumentalnoto nasledstvo na Kirila V"zv"zova-Karateodorova $v$ Nacionalnata biblioteka "Sv. Sv. Kiril i Metodij" (The Documentary Heritage of Kirila Vazvazova-Karateodorova in the National Library "St. St. Cyril and Methodius"). "Poznańskie Studia Slawistyczne" 19. Poznań 2020. Publishing House of the Poznań Society for the Advancement of the Arts and Sciences, Adam Mickiewicz University, pp. 309-318. ISSN 2084-3011.

Kirila Vazvazova-Karateodorova is a notable Bulgarian archivist, archeographer and an author of numerous studies dedicated to the Bulgarian Revival. A small part of the documents related to her landmark are stored in the National Library "St. St. Cyril and Methodius." Although few of these documents reveal part of her personal and creative path.

KeYwords: Kirila Vazvazova-Karateodorova; archivist; Bulgarian Revival; biography

Кирила Възвъзова-Каратеодорова е родена на 25 ноември 1917 г. в гр. Айтос (НБКМ-БИА, ф. 854, а.е. 1, л. 1) в семейство на българи, потомци на участници в борбите за Съединението на Княжество България с Източна Румелия и за освобождението на Македония (Шарова, 1987, 54). Основното си образование завършва в родния си град, след което със семейството си се премества в София. В столицата на Царство България тя завършва Първа софийска девическа гимназия (НБКМ-БИА, ф. 854, а.е. 1, л. 7) и Софийския университет „Св. Климент Охридски“ (НБКМ-БИА, ф. 854, а.е. 1, л. 9) с две специалности история и класическа филология с отличие. Още от студентските си години нейните интереси са насочени към работа върху историята на Българското възраждане и на архивните източници. От 1942 г. до 
1944 г. работи като учителка по история и старогръцки език в Скопие (Драголова, 1988, 58), а след това като редактор в новоучреденото след 9 септември 1944 г. Министерството на информацията, откъдето през 1948 г. се прехвърля в Народна библиотека „Кирил и Методий“ (НБКМ) в отдел „Български исторически архив“ (БИА) (Драголова, 1988, 58). През същата година, след успешно завършен курс по библиотекознание и библиография, и издържан изпит в Народната библиотека, Кирила Възвъзова получава свидетелство за библиотекарска правоспособност (НБКМ-БИА, ф. 854, а.е. 1, л. 16).

До 1964 г. К. Възвъзова-Каратеодорова е асистент, уредник и зам.-ръководител на Български исторически архив, ръководен тогава от университетски преподавател Иван Панайотов. През 1964 г. е назначена от Орлин Василев за главен архивист на НБКМ с ранг на зам.-директор. Същевременно тя е ръководител на научната секция по книгознание, палеография, архивистика и ориенталистика (Калайджиева, 2003, 98). Заради изследователската си дейност е избрана за научен сътрудник през 1954 г., а по-късно (1962 г.) и за старши научен сьтрудник в областта на историческото изворознание. (Шарова, 1987, 54). През 1967 г. като заемащ длъжността главен архивист (1964-1973 г.) в Народната библиотека е изпратена в Париж, на провеждания ежегодно от Националните френски архиви Международен курс по архивистика в Ecole des chartes (при Сорбоната).

С годините, наред с израстването и като административен ръководител, работата на Кирила Възвъзова се свързва и с развитието на архивистиката и археографията в Народната библиотека и в национален мащаб.

През 50-те години дейността на Български исторически архив изпитва затруднения поради неизясненото му положение. Излиза предложение БИА да бъде присъединен към ЦДИА като негов филиал. В опити да се преодолее изолираността на отдела, под ръководството на тогавашния ръководител на БИА д-р Панайотов, заедно с по-млади сътрудници, Кирила Възвъзова съставя Правила за комплектуване, обработка, запазване и използване на документалните материали от личните и обществени архивни фондове и колекции от $X I X-X X$ в., публикувани през 1954 г. (Трашлиева, $2000,33)$. Освен чужди ръководства, предимно съветски, за тяхното 
съставяне са използвани и някои от инструкциите на Държавно архивно управление, в изработката на които вземат участие и сътрудиници на БИА. Тази методическа разработка е пьрвата по рода си у нас и тя е безспорно постижение на младия и амбициозен колектив на БИА.

К. Възвъзова изиграва важна роля в развитието на НБКМ и в частност на Ръкописно-документалния сектор, обединяващ специалните отдели на библиотеката, като негов ръководител. През тези години тя започва основно преустройство на работата в отдела. Използвайки международната архивна теория и практика, Възвъзова извежда отдела до равнището на международно ниво в тази област. Именно по времето, когато Възвъзова ръководи БИА, се прави подредба и научна обработка на документите съхранявани в НБКМ. Под нейно ръководство се изработва и излиза поредицата „Обзори на архивните фондове, колекции и единични постъпления, съхранявани в Български исторически архив“. Също под нейна редакция започва издаването на поредицата „Известия на НБКМ“. След създаването на архивната мрежа в България, Възвъзова става постоянен и ценен съветник в методическата организация по обработката и публикуването на документи от системата на държавните архиви. През 1982 г. участва в съставителския колектив на изданието Правила за публикуване на архивни документи на Главно управление на архивите (Шарова, 1987, 55). Освен като ръководител и администратор, Кирила Възвъзова не спира да се занимава и с научна дейност. Благодарение на нея се създава поредица от полезни справочници, които са в голяма помощ на научния работник. Тя е и инициатор за създаване на научна методика, която се използва не само от Националната библиотека, но и от други учреждения в страната. К. Възвъзова е и автор на повече от 100 заглавия - монографии, студии, статии, научни съобщения, документални сборници и справочници свързани с проблемите на българската архивистика и Българското възраждане (Тилева, 1992, 503).

Името на Кирила Възвъзова-Каратеодорова се свързва с особени заслуги за издирването, научното издаване и интерпретиране на документи свързани с Апостола на българската свобода - Васил Левски. Едни от най-значимите трудове са: Джобния бележник-тефтерчето 
на Левски ${ }^{1}$, Документалното наследство на Васил Левски ${ }^{2}$, Левски във времето. Документално-мемоарен и литературен сборник (Тилева, 1992, 506), Летопис за Васил Левски, Васил Левски. Документално наследство. Юбилейно издание по случай 100 години от гибелma му (Тилева, 1992, 506), като в изданието остават само предговора на Кирила Възвъзова и неговите преводи (Симеонова, 2007, 121). К. Възвъзова има и не малко студии и статии посветени на националноосвободителните борби и делото на Васил Левски: Документалното наследство на Васил Левски Заветите [на В. Левски] и ир. (Тилева, 1992, 509).

Настоящето изследване има за цел да разкрие документите от архивния фонд на К. Възвъзова в Народната библиотека „Св. св. Кирил и Методий“. В него е намерила отражение част от близо 30-годишната творческа дейност на Възвъзова. Документалните материали, свързани с живота и научната дейност на К. Възвъзова постъпват през 1995 г. и са заведени под № 854 - общо 59 документа в периода 1918-1994 г. При научно-техническата обработка на фонда документите са обособени в две архивни единици, подредени в следните класификационни схеми: I - Документи от биографичен характер и II - Документи от научната дейност на К. Възвъзова като историк и архивист.

От биографичните документи във фонда са запазени копие на кръщелното свидетелство (вж. Приложение 1) (НБКМ-БИА, ф. 854, a.e. 1 , л. 1), учебни удостоверения за завършени отделения в Народно основно училище в Айтос, свидетелства от Айтоската народна смесена гимназия „Отец Паисий“ и от Пьрва девическа гимназия - София (1937) (вж. Приложение 1) (НБКМ-БИА, ф. 854, а.е. 1, л. 7); дипломи от Софийския университет „Св. Климент Охридски“ за завършено висше образование (1942) (НБКМ-БИА, ф. 854, а.е. 1, л. 9), от Стажантски учителски курс в София (1942) (НБКМ-БИА, ф. 854, а.е. 1,

\footnotetext{
${ }^{1}$ Като публикатор и интерпретатор на тефтерчето на Левски.

${ }^{2}$ Сборник, на който тя не само е редактор, но и съставител и автор на увода и коментарните бележки.

${ }^{3}$ В: Свята и чиста република. Ямбол, 1973, с. 35-47.

${ }^{4}$ София, 1980, № 2, с. 34-36.

5 „Жената днес“, 1987, № 5, с. 6-8.
} 
л. 14), курс по италиански език в Скопие (1943) и курса за библиотечна правоспособност (1949) (вж. Приложение 1) (НБКМ-БИА, ф. 854, a.e. 1, л. 16) и не на последно място картата ѝ като член на Българското историческо дружество (1990).

Сред документите интерес представляват някои от свидетелствата, на гърба на които лично Възвъзова е оставила бележки с пояснения и интересни факти свързани с тях. На кръщелното свидетелство тя е написала, че кръстницата ѝ Анна Н. Киселова е австрийка (виенчанка) и е съпруга на известния бургаски търговец Никола А. Киселов.

На документа от стажантския учителски курс е отбелязала, че през 1943 г. се явила на държавен изпит: писмен и устен, който положила с отличен, но не е потьрсила документа. На практическия ѝ изпит я е изпитвал Д. Косев, тогава учител по история в VI мъжка гимназия, която се помещавала в сградата на II мъжка гимназия на бул. „Витоша“ (тогава, според Възвъзова ул. Царица Йоанна). Писменият си изпит положила в сградата на I-ва Девическа гимназия с отличен. Като допълнение Възвъзова е посочила, че е била отличник на стажантския курс и че бележката по трета специалност е по латински, за който е положила съответните изпити в гимназията.

Последното свидетелство с коментар към него е това от Първа девическа гимназия, към което Кирила Възвъзова е добавила няколко пояснителни бележки. В първата е отбелязано, че в изброените предмети има пропуск. Пропусната е дисциплината история, която са изучавали във всеки клас. Втората бележка е свързана с успеха, който е 6.88 вместо 5.88, защото е завършила през 1937 г., когато всички оценки са повишени с една единица заради раждането на престолонаследника цар Симеон II. К. Възвъзова изяснява личностите, които стоят зад подписите на дипломата ѝ: Стефан Димитров - директор (наказан като фашист след 9 септември 1944 г.), д-р Гина Ангелова, М. Куманова, В. Нестерова и др. В тази връзка Възвъзова описва Ст. Димитров като отличен ръководител и специалист, и със съжаление отбелязва, че след 9 септември 1944 г. е станал метач по улиците.

По-нататък тя отбелязва, че успехът ѝ е намален, защото е боледувала през годината и дълго време отсъства от учебни занятия поради 
продължителната и тежка болест и последвалата на 5 март 1937 г. смърт на баща ѝ Н. А. Възвъзов.

В последните пояснителни бележки към документа тя описва двете пълни отличнички на випуска, завършили с успех отличен 7: Искра Панова (омъжена по-късно за Чавдар Кюранов) - съученичка и приятелка на Възвъзова, към която тя изпитва най-топли чувства и определя като интелигентна и талантлива, която по-късно се проявява като дейна функционерка на БКП ${ }^{6}$ и Милкана Иванова (сьщо приятелка на Възвъзова) - дъщеря на Димитър Иванов - председател на БНСС (Български национален студентски съюз), чиито архив след 9 септември 1944 г. е имало опасност да бъде унищожен, но Кирила Възвъзова го откупува за БИА.

Сред документите от личен произход е запазено и копие на грамотата, издадена от Народната библиотека в София (1979) (НБКМ-БИА, ф. 854, a.e. 1, л. 17), за награждаването на К. Възвъзова за „изключително големи заслуги при изграждането, утвърждаването и развитието на Народната библиотека »Кирил и Методий« като Национален архив на Възраждането, най-богата съкровищница на българската ръкописна книга, единствено хранилище на ориенталски ръкописи и документи“ (НБКМ-БИА, ф. 854, а.е. 1, л. 17).

Значителна част от фонда ѝ се заема от отпечатъци на публикации отразяващи нейната дългогодишна работа като архивист и историк. Хронологическият обхват на изследванията ѝ засяга бегло периода от историята на българските земи XV-XVII в. (НБКМ-БИА, ф. 854, a.e. 2 , л. 237 a). Най-голям обхват в нейните публикации има историята на Българското възраждане. Съществено място заема темата за Априлското въстание, участниците в него, политическия му отзвук у нас и в чужбина. Подвигът на Хр. Ботев и неговата чета са интересно представени в статията Писмени исторически извори от 1875/1876 2. за военната подготовка и провеждането на Априлското въстание u за Ботевата чета (НБКМ-БИА, ф. 854, а.е. 2, л. 617). В запазените отпечатъци от фонда на К. Възвъзова се съдържат и заглавия засягащи личности като К. Иречек, Г. Раковски, В. Левски, Т. Пеев и др.

${ }^{6}$ Дъщеря на Йордан Панов и Йорданка Панова - активни дейци - интелектуалци, изцяло подкрепящи БКП. 
Фондът се допълва с публикации свързани с организацията, обработката и публикуването на архивни документи, като Прошлое, настоящее и предстоящее задачи организации и обработке архивов литературь и изкусств в Болгарии (НБКМ-БИА, ф. 854, а.е. 2, л. 442) и По някои проблеми, свързани с научно-издателската дейност на нашите архиви (НБКМ-БИА, ф. 854, а.е. 2, л. 754) и др.

Макар и мальк, фондът на К. Възвъзова-Каратеодорова съхраняван в Националната библиотека „Св. св. Кирил и Методий“ е изключително ценен, тъй като съхранява част от личния и творческия път на един от най-изтъкнатите представители на архивното дело в България. Този архив дава макар и бегла възможност да се направи една по-обща равносметка на работата и дейността на К. Възвъзова. Приносът ѝ за развитието на Български исторически архив към Народната библиотека е безспорен. Под нейно ръководство БИА има заслуги по отношение на методическото осигуряване на дейността свързана с обнародването на архивни документи. Благодарение на високата си професионална квалификация и натрупания в хода на работа опит върху публикуването на архивни документи, К. Възвъзова има съществен принос за съставянето на задължителните за страната общи методически изисквания във връзка с публикуването на писмени исторически извори.

Това, което К. Възвъзова оставя след себе си като архивист, археограф, научен работник и административен ръководител е забележително и може да бъде пример за бъдещите поколения.

\section{Използвани архивни фондове}

Национална библиотека „Св. Св. Кирил и Методий“ - Български исторически архив (НБКМ-БИА), ф. 854, оп. 1, a.e. 1.

Национална библиотека „Св. Св. Кирил и Методий“ - Български исторически архив (НБКМ-БИА), ф. 854, оп. 1, а.е. 2.

[Nacionalna biblioteka „Sv. Sv. Kiril i Metodij“ - B"lgarski istoričeski arhiv (NBKM-BIA), f. 854, op. 1, a.e. 1.

Nacionalna biblioteka „Sv. Sv. Kiril i Metodij“ - B”lgarski istoričeski arhiv (NBKM-BIA), f. 854, op. 1, a.e. 2]. 


\section{Литература}

Драголова, Л. (1988). Кирила Възвъзова на 70 години. „Векове“ № 1, с. 58-61.

Калайджиева, К. (2003). Материали за историята на Народната библиотека „Св. св. Кирил и Методий“ 1944-1978. София: Нар. библ. „Св. Св. Кирил и Методий“".

Симеонова, Р. (2007). Кирила Възвъзова и документалното наследство на Васил Левски. Смисълът на един живот. „Българско Възраждане - идеи, личности, събития: годишник на Общобългарски комитет и Фондация »Васил Левски«“ № 9, с. $118-126$.

Тилева, В. (1992). Кирила Възвъзова-Каратеодорова на 75 години: [Биобиблиогр.]. „Известия на Народната библиотека »Св. св. Кирил и Методий«““ № 20 (26), c. 501-515.

Трашлиева, Л. (2000). Български исторически архив при Народна библиотека „Св. Св. Кирил и Методий” - история и съвременност. „Известия на държавните архиви“ кн. 80, с. 31-58.

Шарова, К. (1987). Научното дело на Кирила Възвззова-Каратеодорова. „Исторически преглед“ № 12, с. 53-65.

[Dragolova, L. (1988). Kirila V"zv"zova na 70 godini. ,Vekove“ № 1, s. 58-61.

Kalajdžieva, K. (2003). Materiali za istoriâta na Narodnata biblioteka „,Sv. sv. Kiril i Metodij“ 1944-1978. Sofiâ: Nar. bibl. „Sv. Sv. Kiril i Metodij“.

Simeonova, R. (2007). Kirila V"zv"zova i dokumentalnoto nasledstvo na Vasil Levski. Smis"l"” t na edin život. „B"lgarsko V"zraždane - idei, ličnosti, s”bitiâ: godišnik na Obŝob"lgarski komitet i Fondaciâ »Vasil Levski«“" № 9, s. 118-126.

Tileva, V. (1992). Kirila V"zv"zova-Karateodorova na 75 godini: [Biobibliogr.]. „Izvestiâ na Narodnata biblioteka »Sv. sv. Kiril i Metodij«“№ 20 (26), s. 501-515.

Trašlieva, L. (2000). B"lgarski istorič eski arhiv pri Narodna biblioteka ,Sv. Sv. Kiril $i$ Metodij” - istoriâ $i$ s"vremennost. "Izvestiâ na d"ržavnite arhivi“" kn. 80, s. $31-58$.

Šarova, K. (1987). Naučnoto delo na Kirila V"zv"zova-Karateodorova. „Istoričeski pregled““ № 12, s. 53-65]. 


\section{Приложение 1}

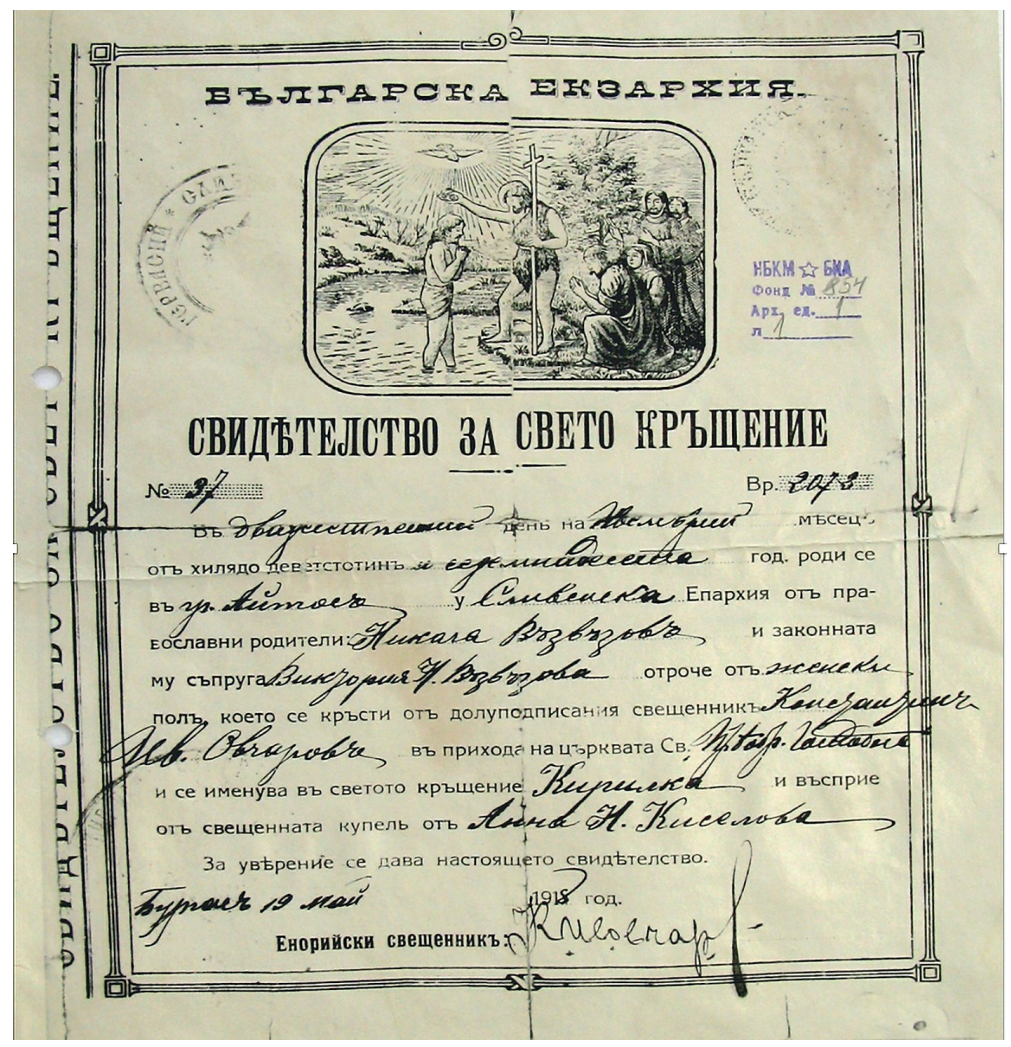

Фот. 1. Кръщелно свидетелство. НБКМ-БИА, ф. 854, а.е. 1, л. 1. Оригинал. 


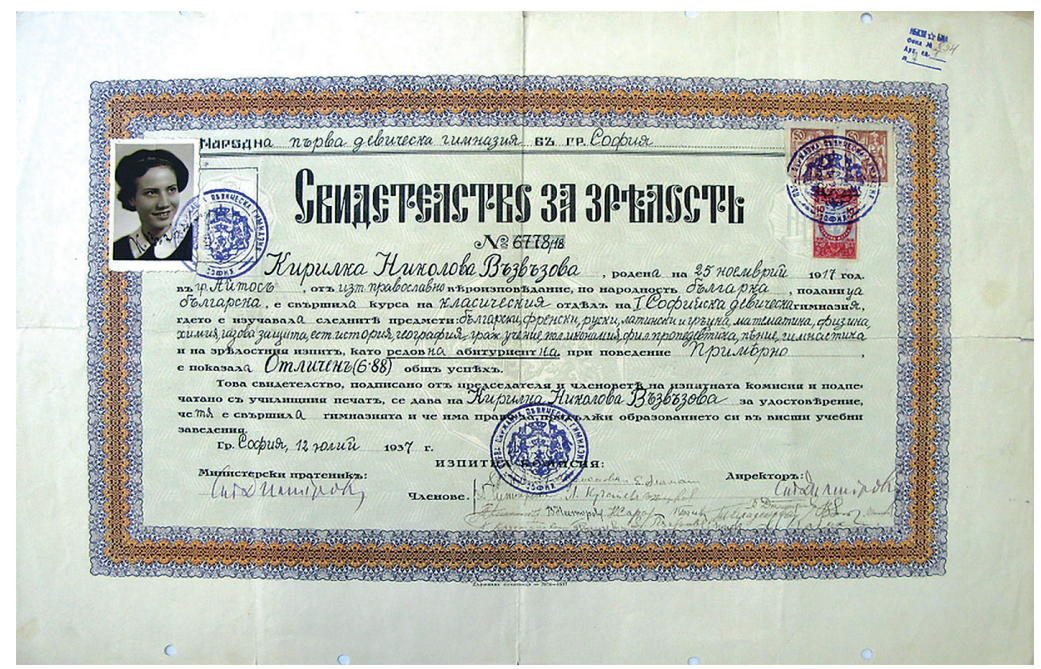

Фот. 2. Свидетелство за зрелост от Пьрва девическа гимназия - София (1937). НБКМ-БИА, ф. 854, а.е. 1 , л. 7. Оригинал.

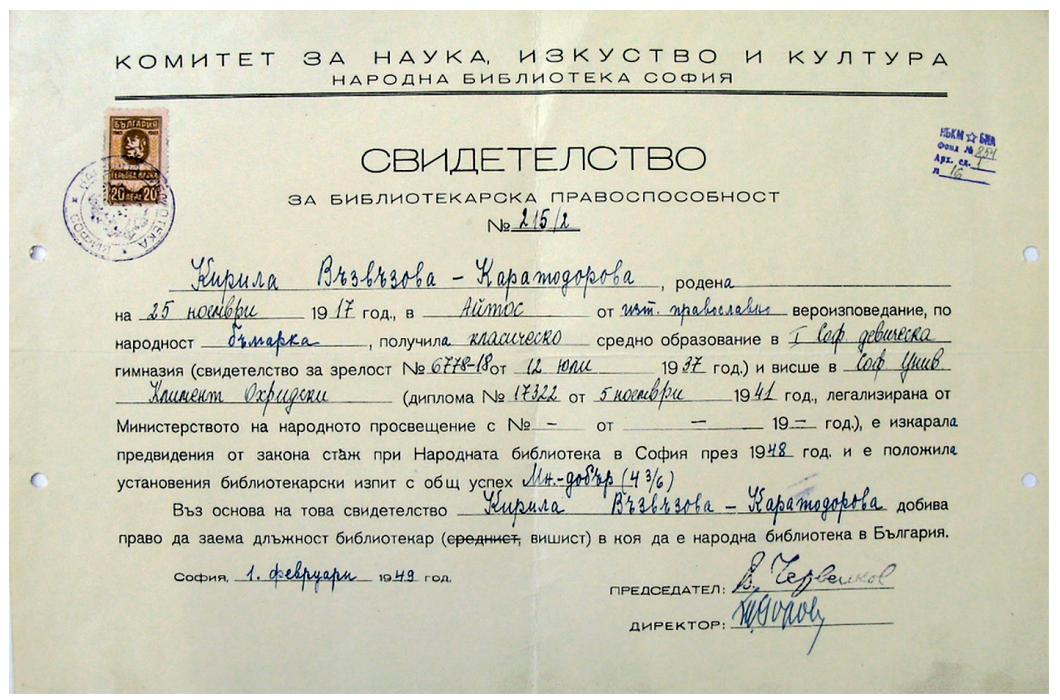

Фот. 3. Свидетелство за завършен курс за библиотечна правоспособност (1949). НБКМ-БИА, ф. 854, а.е. 1, л. 16. 